\title{
OM DEN NORDISKA KRIMINALPOLITIKENS UTVECKLING
}

\author{
AV PROFESSOR RAIMO LAHTI
}

Ideological trends in the criminal policy of the Nordic countries since the 1960 's are analyzed. Although criminal policy in these countries is not unified, one can argue for the existence of a "Nordic criminal policy" characterized by several common features concerning historical tradition, intensive cooperation, and a similar approach to crime prevention and control. The following trends and characteristics are examined in some detail: the cycle from criticism of the treatment ideology to a reappraisal of the role of penal systems and criminal sanctions; the differentiation of criminal policy strategies (e.g., social and situational crime prevention, cost-benefit thinking, criminal law policy, sanction policy).

The term "criminal policy" is used in a broad sense, encompassing the totality of public decisions and debate relating to the prevention, control, and sanctioning of crime, as well as to the actions of the formal criminal justice system. A distinction between theoretical and practical criminal policy is made, the main emphasis being given to the theoretical approach and to the argument for a rational and humane criminal policy. Some foreseeable trends towards more punitive policies are critically analyzed.

Discernible tendencies towards more unified or, at least, more harmonized criminal policies on the international and European level are examined. Active participation in this developmental process is encouraged to ensure that the fundamental principles of Nordic criminal policy are properly utilized. *

\section{Inledning}

Temat om den nordiska kriminalpolitikens utveckling är så omfattande, att perioden och synvinkeln för granskningen måste begränsas. Jag har personligen följt denna utveckling sedan 1967, då jag som ung assistent i straffrätt för första gången deltog $\mathrm{i}$ ett nordiskt kriminalistmöte (i ordningen det sjätte) $\mathrm{i}$ Stockholm. Samma år höll Inkeri Anttila sitt välkända föredrag om "Konservativ och radikal kriminalpolitik i Norden" $(1967)^{1}$, som har varit en inspirationskälla för min följande framställning. Sålunda skall jag granska kriminalpolitikens utveckling under de senaste årtiondena, delvis utgående från mina subjektiva iakttagelser och mitt eget deltagande i den finska kriminalpolitiken under de senaste tre årtiondena. ${ }^{2}$

* Title in English: Trends in Nordic Criminal Policy. Original in Swedish. 
Granskningen skall inte endast rikta sig bakåt, utan min synvinkel avser även att vara utvärderande och framtidsorienterad. Har den nordiska kriminalpolitiken varit framgångsrik? Vilka är den nordiska kriminalpolitikens utmaningar för det 21 århundradet? Är vi på väg mot en internationell och europeisk kriminalpolitik, samtidigt som den nordiska kriminalpolitiken är i fara att mista mycket av sin positiva betydelse?

Att tala om den nordiska kriminalpolitiken är generaliserande och i viss mån idealiserande: kriminalpolitiken har inte varit enhetlig i de olika nordiska länderna, men väsentliga gemensamma drag kan säkerligen urskiljas i synnerhet från ett längre avstånd. Vi är medvetna om våra gemensamma historiska rättstraditioner, och samnordiska organ och olika samarbetsformer mellan de nordiska länderna har närmat våra rättssystem. Exempelvis artikel 5 i den nordiska samarbetsöverenskommelsen (1962) stadgar, att de fördragsslutande parterna bör eftersträva enhetliga bestämmelser om brott och brottspåföljder. Beträffande brott, som begåtts $\mathrm{i}$ ett nordiskt land, bör enligt samma artikel utredning och lagföring i största möjliga utsträckning kunna ske även i ett annat nordiskt land. Enhetlig lagstiftning beträffande nordiskt samarbete vid brottslighetskontroll och direkta myndighetskontakter underlättar i dessa länder betydligt mellanstatliga åtgärder i brottmålsärenden.

Såsom närmare framförs senare, är det mer och mer viktigt att identifiera, vad - i synnerhet vilka värdemålsättningar - som är, och vad som borde vara, kännetecknande för den nordiska kriminalpolitiken, när tendensen till kriminalpolitikens internationalisering och europeisering tydligt kan skönjas.

\section{Om begreppet kriminalpolitik och dess omvandlingar}

Jag använder begreppet kriminalpolitik i en vidsträckt mening: det är en totalitet som omfattar samhälleliga beslutsfattanden och diskussioner beträffande brottsförebyggande samt kontroll och sanktionering av brottslighet. Med brottslighet skall jämställas annat avvikande beteende för vilket punitiva sanktioner kan användas. Denna utvidgning från (snäv) kriminalpolitik till kontrollpolitik är viktig bl.a. för att man skall kunna ta hänsyn till EG:s sanktionsrätt och kunna värdera den europeiska kriminalpolitiken. ${ }^{3}$

Sagda definition hänvisar till kriminalpolitikens praktiska uttrycksform samhälleligt beslutsfattande som rör brottslighet och dess bekämpande. Begreppet har även en teoretisk-vetenskaplig dimension: forskning beträffande kriminalpolitik, varvid termen är nära rättspolitisk forskning och tillämpad kriminologi. Den kriminalpolitiska forskningen kan räknas som en del av kriminalvetenskaperna, särskilt vid sidan av straffrättsvetenskapen och kriminologin. I synnerhet i Finland har det ansetts viktigt att ställa kriminologins problemformuleringar i relation till det samhällspolitiska beslutsfattandet, dvs. till den praktiska kriminalpolitiken. ${ }^{4}$ Den teoretisk-vetenskapliga dimensionen av kriminalpolitiken omfattar även möjligheten att kritisera det faktiska kriminalpoli- 
tiska beslutsfattandet och den gällande straffrätten samt utveckla en kritisk teori därom. ${ }^{5}$

I denna framställning har jag närmast den teoretiska dimensionen i tankarna, dvs. en sådan kriminalpolitik som på kunskapsmässiga och (andra) rationella grunder kan motiveras. Samtidigt är det önskvärt, att det funnes en fruktbar växelverkan mellan teoretisk och praktisk kriminalpolitik. Oftast torde spänningar och även motsättningar råda mellan dem, då den praktiska kriminalpolitiken är kraftigt påverkad av allmänpolitiska värderingar och känslomässiga attityder. ${ }^{6}$

Begreppsanalysen är inte utan substantiella implikationer, när man granskar kriminalpolitikens utvecklingsskeden. De förändringar som under tidernas lopp har skett inskränker sig inte till variationer beträffande brottsligheten samt dess förebyggande, kontroll och sanktioner. Man bör även fråga sig, vilka förändringar som har skett i uppfattningarna om brottsligheten och dess bekämpande, dvs. om kriminalpolitiken och dess tyngdpunkter. Man kan t.ex. ställa följande frågor: Vilka ideologiska och kunskapsmässiga faktorer har påverkat den nordiska kriminalpolitiken sedan 1960-talet? Hur förhåller sig dessa utvecklingsskeden till den kriminologiska forskningen och den kriminalpolitiska teoribildningen? I vilken mån har den praktiska kriminalpolitiken baserat sig på forskning och rationell argumentation; hurudan växelverkan mellan praxis och teori är realistisk i framtiden?

Inkeri Anttila insåg i sitt ovannämnda föredrag att det avgörande för motsatsen konservativ/radikal kriminalpolitik i Norden är meningsskiljaktigheten beträffande den hastighet med vilken institutioner, värderingar, legala system och attityder skall förändras. Hon själv tycks ha sympatiserat med den radikala kriminalpolitiken, som skulle utgå från en medvetet balansorienterad ideologi och som skulle vara beredd till en snar realisering av sådana reformplaner som avkriminalisering och brottsprevention. Hon rekommenderade en analys av de skönjbara trenderna i den nya kriminalpolitiken, bl.a. för att skapa ett underlag för en medveten planering av den kriminologiska forskningsstrategin.?

\section{Från kritiken av behandlingsideologin till omprövningen av det straff- rättsliga systemets roll och sanktionernas funktioner ${ }^{8}$}

Den vetenskapliga kriminalpolitikens ursprung härleds normalt från Franz von Liszts och liksinnades sociologiska (moderna) straffrättsskola. Dess bakgrund bestod av det positivistiska vetenskapsidealet. Som väl känt, riktades denna skolas viktigaste kriminalpolitiska verkan mot det straffrättsliga sanktionssystemet. Vid fastställandet av straffrättsliga påföljder borde större uppmärksamhet fästas vid gärningsmannens personlighet än vad som var möjligt med beaktande enbart av de egenskaper som framgick ur hans enskilda brottsliga gärning. Den centrala - om inte uteslutande - grunden vid valet av påföljdsart skall vara gärningsmannens behov av behandling (vård) eller hans farlighet.

Den nya ideologin spreds snabbt och påverkade redan innehållet i många 
strafflagsförslag som tillkom i Europa i slutet av 1800-talet. Dess inverkan framgick likväl ännu tydligare ur de förslag och förverkligade reformer av strafflagstiftningen som utarbetades i början av 1900-talet. De norska professorerna Francis Hagerup och Bernhard Getz gjorde i Norden en banbrytande insats för förverkligandet av den sociologiska skolans program. Den norska strafflagen av år 1902, vars tillkomst och innehåll Getz påverkade på ett väsentligt sätt, ansågs vara sin tids modernaste.

Individualprevention betonades sedan i Norden, liksom även annorstädes i Europa och i USA, under gott och väl den första hälften av 1900-talet. Tydligast märkte man de individualpreventiva tankegångarnas ökade inflytande i de olika nordiska länderna i skapandet av specialpåföljder för å ena sidan unga lagöverträdare, och å andra sidan psykiskt abnorma och återfallsförbrytare. Även införandet av villkorlig dom (i Norge 1894, Danmark 1905, Sverige 1906 och Finland 1918) härstammade från den sociologiska skolans program. ${ }^{9}$

Guldåldern i Norden för tidsobestämda eller individualiserade påföljder, som antingen grundade sig på en strävan till behandling eller ett oskadliggörande, varade i ungefär tre årtionden. Det är likväl skäl att notera, att den individualpreventiva ideologin ingalunda verkade med samma styrka överallt i Norden och från och med slutet av 1960-talet rönte ideologin mer och mer kritik. Upphovsmän till kritiken var närmast vissa norska och finska kriminologer, såsom Nils Christie och (sammanfattande) Inkeri Anttila.$^{10} \mathrm{Om}$ temat utkom också flera debattböcker, bland de främsta "Varning för vård" (1967) och "Behandling som straff" (1969).."

Kritiken baserade sig på olika argument. Genom den ökade kriminologiska kunskapen hade man inte kunnat finna sådana behandlingsmetoder som vid en minskning av återfallsbenägenheten kännbart och allmänt vore bättre än andra. Bl.a. de undersökningar om dold brottslighet som gjorts i de nordiska länderna under 1960-talet, hade för sin del bidragit till att bräcka uppfattningen om att ett genomsnittligt brott vore ett symptom på någon psykisk sjukdom eller motsvarande abnormitet. Kritiken baserade sig i väsentlig mån på principiella synpunkter: dvs. på de brister i rättssäkerheten som ansluter sig till en långtgående individualisering av påföljder. Tidsobestämda sanktioner, som fastställs enligt gärningsmannens behov av behandling eller hans farlighet, ansågs strida mot sådana viktiga rättsprinciper som proportionalitet och likställighet, eller mera allmänt mot rättvisa och förutsägbarhet.

Kritiken mot behandlingstanken och omprövningen av det straffrättsliga systemets roll var centrala teman i de officiella organens principutredningar, som blev färdiga under åren 1977-1978 i de olika nordiska länderna: betänkande utgivet av den finska straffrättskommittén, det svenska Brottsförebyggande rådets rapport "Nytt straffsystem", det norska Justis- og politidepartementets kriminalpolitiska tillkännagivande till Stortinget ("Kriminalmeldingen") samt det danska betänkandet "Alternativer till frihedsstraf". ${ }^{12}$ 
Dessa utredningar återspeglade en ny kriminalpolitik, som oftast benämnes "nyklassisism", emedan den nya riktningen ansågs ha vissa beröringspunkter med 1800-talets klassiska straffrätt - närmast nog med dess grunder som låg $\mathrm{i}$ upplysningsfilosofin och rättsstatstänkandet. Den nya kriminalpolitiken diskuterades vid det åttonde kriminalistmötet i Oslo år 1979, och följande år utkom en samnordisk debattbok "Straff och rättfärdighet" om temat. ${ }^{13}$

Redan från början visade det sig omöjligt att klart definiera vad denna nya kriminalpolitik innehåller. Ganska entydigt lade man vikt vid rättvisa, rättssäkerhet och humanitet som vägledande rättsprinciper för det straffrättsliga systemet, samtidigt som straffsystemets allmänpreventiva verkan värderades. Avvägningen av dessa värden och intressen varierade så, att t.ex. i de danska och norska utredningarna var argumentationen pragmatisk och konsekvensorienterad - för kravet att reducera bruket av straff och utveckla alternativ till frihetsstraff. En nyrenässans av allmänprevention förordades i de finska och svenska utredningarna, närmast $i$ betydelsen positiv allmänprevention och "moraldanning" (straffsystemets indirekta verkan på moralen och människornas laglydighetsattityder) i motsats till enbart avskräckning ${ }^{14}$. Den nya straffrättsideologin torde tydligast ha påverkat lagstiftningen om straffmätning i Finland (1976) och Sverige (1989). ${ }^{15}$ Det må nämnas, att i Danmark ändrades strafflagstiftningen redan år 1973 med avsikt att upphäva möjligheterna till tidsobestämda sanktioner. ${ }^{16}$

Utan att binda mig till benämningen "nyklassisism" skall jag i det följande närmare analysera kriminalpolitikens utveckling ända till sekelskiftet utgående från de tyngdpunkter som framgick av sagda principutredningar (i synnerhet av den finska straffrättskommitténs betänkande). Samtidigt försöker jag mig på en värdering och framtidsorientering: hur har man lyckats i den förnyade kriminalpolitiken och vilka är dess hotbilder och möjligheter i framtiden - då en ökad internationalisering av kriminalpolitiken gör sig gällande?

\section{En differentiering av kriminalpolitiska strategier (I): samhällsplanering och brottsförebyggande}

De ovannämnda finska, svenska och norska principutredningarna (1977-1978) granskade kriminalpolitiken som en del av samhällspolitiken, fastän deras huvudvikt låg i omvärderingen av det straffrättsliga sanktionssystemet. Det var viktigt att inse det straffrättsliga systemets begränsade verkan på brottslighetens nivå eller dess struktur och att bli medveten om samhällsplaneringens och brottsförebyggande åtgärders roll som alternativ eller komplement till de straffrättsliga medlen.

Som en konsekvens av sagda insikt borde prioritetsordningen av kriminalpolitiska medel ändras samt planeringen och beslutsfattandet göras mångsidigare. Enligt denna målsättning har försök gjorts att främja samarbetet mellan myndigheterna, organisationerna och medborgarkretsarna i brottslighetsfrågor och 
att förbättra koordineringen av brottsförebyggande åtgärder. I detta syfte grundades särskilda koordinerings- och utredningsorgan, först i Danmark "Det kriminalpræventive råd" (1971) och i Sverige "Brottsförebyggande rådet" (1974); sedermera har motsvarande rådgivande organ stiftats även i Norge och Finland.

Intresset för brottspreventionen och dess forskning har ökat under de senaste tiderna. ${ }^{17}$ Nationella brottsförebyggande program har nyligen antagits både $\mathrm{i}$ Sverige (1996) och Finland (1999). Traditionellt har man i Norden satsat på de mjuka åtgärderna, dvs. allmän eller social brottsprevention, men senast har rollen av den situationella preventionen (det omedelbara förhindrandet av brott) tilltagit mer intensivt - i den mån att kritiska röster bl.a. emot den ökande sociala segregationen och privatiseringen av rättssystemet har höjts i debatten. ${ }^{18}$

Syftet att tillämpa allmänna samhällspolitiska planeringsmetoder eller liknande argumentationsmodeller inom kriminalpolitiken tog sig i Finland uttryck bl.a. i ett mera differentierat sätt att specificera målen och medlen för kriminalpolitiken. Man definierade de speciella målsättningarna för kriminalpolitiken: (a) att minimera det lidande och de andra individuella och sociala kostnader (skador, olägenheter) som förorsakas av brottsligheten och av samhällets åtgärder mot brottsligheten, samt (b) att fördela dessa kostnader rättvist. ${ }^{19}$ Den ledande värdemålsättningen är alltså, att brottsligheten inte bör minimeras till vilket pris som helst. För mätningen av konstnader behövs indikatorer på brottslighetsskador och kontrollskador. Man borde sträva efter en så förmånlig proportion som möjligt mellan dessa typer av kostnader och efter en så rättvis distribution av kostnaderna som möjligt.

Två finska kriminologer Patrik Törnudd och Tapio Lappi-Seppälä har nyligen värderat, hur de sagda målsättningarna har förverkligats i Finlands kriminalpolitik. ${ }^{20}$ Man har t.ex. jämfört fångtalet och registrerade brott mot strafflagen i fyra nordiska länder (Finland, Danmark, Norge och Sverige) ända från år 1950 samt granskat internationella offerundersökningar. Fångtalet i Finland hade halverats, medan det i de andra länderna hade hållits på ungefär samma nivå; trots detta var utvecklingen av strafflagsbrotten mycket likadan. Sålunda hade man minskat de mänskliga lidandena och nått omfattande materiella inbesparingar utan att brottslighetsutvecklingen var väsentligen annorlunda än vad den annars sannolikt hade varit. ${ }^{21}$

Kriminalpolitikens framgång är inte möjlig att entydigt mäta. Sagda målsättningar kräver nog ökad värde-, kostnads- och alternativmedvetenhet i kriminalpolitiken, men det nya tänkesättet löser inte den prioritering och det sammanvägande av olika värden och intressen som i den samhällspolitiska planeringen och beslutsfattandet måste göras. Kravet att kriminalpolitiken i större omfattning borde basera sig på empirisk och annan forskning utesluter inte värderingars roll; snarare blir man bättre medveten om dem. ${ }^{22}$

$\AA$ andra sidan borde man förutsätta att kriminalpolitikens mål och medel dryftas på ett sätt som uppfyller de allmänna rationalitetskraven för diskussion. ${ }^{23}$ 
Med Nils Jareborgs ord: gör värderingarna "mer reflekterte" i betydelsen "mer övervägda, mer rationella". ${ }^{24}$ I denna rationalitetsdiskussion visar sig kriminalvetenskaperna som närstående till sådana discipliner som moral- och samhällsfilosofin, politikvetenskapen, socialteorin och rättsekonomin. ${ }^{25}$

\section{En differentiering av kriminalpolitiska strategier (II): straffrätts- och sanktionspolitik}

Ett gemensamt drag för de ovannämnda principutredningarna från åren 1977 1978 var en skarp kritik mot dåvarande straffsystem, i synnerhet mot tidsobestämda straff men också mot frihetsstraff $\mathrm{i}$ allmänhet. Kravet på humanitet och målet att minimera kontrollskador talade för mildare straff och alternativ till frihetsstraff. Utvecklingen på 1980- och 1990-talen ledde inte till en sådan minskning av repression som dessa utredningar förordade - med undantag av Finlands nedgående fångtal (se ovan 4). I de andra nordiska länderna har fångtalet under de senaste årtiondena hållit sig ganska stabilt ${ }^{26}$, men i andra hänseenden förändrades det kriminalpolitiska klimatet särskilt i Sverige och Norge och blev kyligare mot slutet av 1980-talet.

Ändringens orsaker och framtidsutsikter analyserades i två antologier "Nordiska kriminologer om 90-talets kriminalpolitik" (1990) och "Varning för straff" (1995); författarna av det senare verket var delvis samma personer som bidrog till den tidigare debattboken "Straff och rättfärdighet" (1980). ${ }^{27}$ Alldeles i slutet av 90-talet utkom på initiativ av Sveriges Brottsförebyggande råd ännu en antologi om kriminalpolitikens utvecklingsbehov på tröskeln till det 21 århundradet. $^{28}$

Dessa antologier täcker de olika dimensionerna av kriminalpolitiken, och de är särskilt inspirerande när man kritiskt dryftar kriminalpolitikens hotbilder och framtidsmöjligheter (se nedan 6). Vad beträffar straffrätts- och sanktionspolitik, är i synnerhet Nils Jareborgs artikel - en slags teoretisk referensram för hela antologin "Varning för straff" - viktig för diskussionen. ${ }^{29}$ Jareborg skiljer mellan defensiv och offensiv straffrättspolitik. Det är fråga om två idealtypiska modeller för beslutsfattande som rör det straffrättsliga systemet (närmast: principer för kriminalisering, de straffprocessuella rättssäkerhetsgarantierna samt principer för påföljdsbestämning och verkställighet av påföljd). Jareborg förordar den defensiva modellen, vars principer och garantier motsvarar en rättsstatlig straffrättsideologi (dvs. den "sammanfatta[r] grundläggande värderingar i en rättsstat").

Den offensiva inriktningen, där åtskilligt i den defensiva modellen kan lämnas oförändrat, är samhällsteknologiskt orienterad och för den är prevention den dominerande synpunkten. Jareborgs beskrivning av denna inriktnings metoder och konsekvenser synes motsvara drag hos en välfärdsstatlig straffrättsideologi. Modern strafflagstiftning, t.ex. de straffstadganden om ekonomiska brott och arbets- och miljöbrott som har förnyats under totalrevisionen av den finska 
strafflagen sedan år $1990^{30}$, fyller typiskt många av den offensiva inriktningens kännetecken och är utsatt för kritik utgående från rättssäkerhets- och legitimitetsaspekter.

De kritiska aspekter som kan framföras mot den offensiva inriktningen måste enligt min mening beaktas. Samtidigt borde man sträva efter en väl balanserad avvägning mellan rättsstatlig- och välfärdsstatlig straffrättsideologi. ${ }^{31}$ Straffrättsteorin måste utvecklas så att den ger strafflagsberedningen och straffrättsskipningen systematiska och principiella argument för att skydda individer mot maktmissbruk och begränsa bruket av straffrätt. Det tilltagande människorättsoch grundrättighetstänkandet, som har dominerat den finska rättsteorin från 1990-tale ${ }^{32}$, är uppenbarligen mycket befruktande för denna teoribildning. ${ }^{33}$

I sanktionspolitiken innehåller de på 1990-talet publicerade antologierna ganska litet nytt i förhållande till principutredningarna från åren 1977-1978. Det är närmast kravet på human straffrättspolitik, som förordar en minskad användning av frihetsstraff, och rättssäkerhetsaspekterna, som talar emot oskadliggörandet (inkapacitering) av lagöverträdare. ${ }^{34}$ Ändå har det skett vissa försiktiga förändringar i lagstiftningen, i attityderna till individualiserade påföljder och i behandlingstanken; den kriminalpolitiska pendeln har svängt något åt andra hållet.

Samhällstjänst, som det danska betänkandet "Alternativer till frihedsstraf" (1977) föreslog att skulle införas, har sedermera tagits i bruk inte bara i Danmark $(1982,1992)$ men även i de andra nordiska länderna..$^{35}$ T.ex. i Finland dömdes år $199843 \%$ - ca 4.000 åtalade (de flesta rattfyllerister) - av dem som dömdes till ovillkorliga fängelsestraff $i$ högst 8 månader (vilket är maximum för att samhällstjänst kan prövas) i stället till denna frivårdspåföljd. ${ }^{36}$

Förlikning mellan gärningsmannen och målsäganden eller andra former av alternativ konfliktlösning (konfliktrådsverksamheten) har också införts som nya påföljdstyper i de nordiska länderna; dessa sanktioner representerar en privatisering av rättssystemet och en prioritering av den reparativa funktionen av rättskipning. "Restorativ rättskipning" -inriktningen har ändå inte vunnit någon stark genklang i Norden. Tendensen är nog mot en försiktig förstärkning av denna inriktning. ${ }^{37}$

Behandlingstankens moderata renässans visar sig i rehabiliteringsprogram som numera har genomförts inom fångvården och i de behandlingsåtgärder som har (närmast i Danmark) införts som alternativ till fängelse. ${ }^{38}$

\section{Om kriminalpolitikens hotbilder och framtidsutsikter}

I den akademiska diskussionen har sedan 1990-talet väckts farhågor om, hur det praktiska beslutsfattandet kunde styras av de teoretiskt hållbara premisserna för en rationell och human kriminalpolitik. Denna oro var en dominerande egenskap i de ovannämnda antologierna "Nordiska kriminologer om 90-talets kriminalpolitik" (1990) och "Varning för straff" (1995). 
I diskussionen har hänvisats till flera faktorer, som har minskat möjligheterne för kommunikativ rationalitet (systematisk och principiell argumentation) i kriminalpolitiken. I synnerhet massmediernas och allmän- eller partipolitikens ökande roll har härvid nämnts; straffrättspolitikens repressiva åtgärder har allt oftare vidtagits i moralisk panik. ${ }^{39}$ Exemplen på denna utveckling varierar något mellan de olika nordiska länderna och på olika områden ${ }^{40}$ (narkotikakontrollen är det tydligaste exemplet på en hård kriminalpolitik i kontrast till vår idealbild av nordisk kriminalpolitik) ${ }^{41}$. I Finland har man tillsvidare kanske bäst kunnat undvika populism och osaklik politisering av brottslighetsfrågorna. ${ }^{42}$

Sagda spänning, till och med konflikt, mellan teoretisk och praktisk kriminalpolitik är en svår utmaning för forskningen och forskarna. En lösning är att med olika medel förbättra dialogen mellan forskare, praktiker, journalister och politiker samt att säkerställa medborgarnas på upplysning baserade deltagande $\mathrm{i}$ den praktista kriminalpolitiken. ${ }^{43}$ Nyckelbegreppet beträffande straffrättssystemet är legitimitet: människorna måste lita på systemet, uppleva det som legitimt. ${ }^{44} \mathrm{Med}$ Johs. Andences' ord: "Det vil si et system som gir et rimelig vern mot samfunnsmessig uønskede handlinger uten å komme i strid med våre forestillinger om humanitet og rettferdighet.".45

Straffrättssystemet reflekterar alltid samhällets strukturella och kulturella faktorer. Om samhällets repressionsnivå stiger, är det skäl att fråga efter orsakerna i anknytning till dessa faktorer; kriminalitetsutvecklingen är sällan en tillräcklig förklaring till ändringen ${ }^{46}$ Ökande repression i ett samhälle ger skäl till frågor om dess tillstånd: t.ex. hur väl demokratin fungerar och vilka brister på jämlikhet kan uppvisas. ${ }^{47}$

\section{Exkurs till internationaliseringen och europeiseringen av kriminalpoliti- ken - Är denna utveckling ett hot eller en möjlighet? ${ }^{48}$}

Internationaliseringen av kriminalpolitiken kan observeras från olika tecken. För det första håller den internationella straffrättens system på att starkt ta form. En krigsförbrytardomstol, som handlägger brott begångna inom det forna Jugoslaviens område, inrättades i Haag medelst en resolution 827 (1993) som FN:s säkerhetsråd antagit. Ett år senare grundades en motsvarande ad hoc -domstol i syfte att handlägga folkrättsbrott, dvs. allvarliga kränkningar av den humanitära rätten, som begåtts i Rwanda. Dessa domstolars grundstadgor, kompletterande procedur- och bevisningsregler samt ifrågavarande avgörandepraxis bidrar starkt till utvecklingen av den internationella straffrätten och doktrinen angående den. Vid FN:s diplomatkonferens i Rom i juli 1998 godkändes en grundstadga om en permanent internationell brottmålsdomstol.$^{49}$ Den internationalla straffrättens utveckling har varit snabbare än man kunde vänta sig t.ex. vid det 11 nordiska kriminalistmötet i København år 1994. ${ }^{50}$

För det andra ser man bekämpandet av brottsligheten och utvecklandet av de straffrättsliga systemen allt klarare som världsomfattande uppgifter. Följande 
internationella åtgärder som förverkligats på 1990-talet får tjäna som exempel: Vid ministerkonferensen, som anordnades i Neapel år 1994, godkändes en politisk deklaration och en global plan angående bekämpandet av den organiserade, staternas gränser överskridande brottsligheten, och därefter har temat varit föremål för talrika uppföljande åtgärder. FN:s kriminalpolitiska program hade byggts upp på nytt redan 1991, då man medelst $\mathrm{FN}$ :s resolution 46/152 grundade FN:s kriminalpolitiska kommission (UN Commission on Crime Prevention and Criminal Justice). Under de allra senaste åren har man bearbetat programmet vidare så, att dess tyngdpunkt nu ligger i bekämpandet av den organiserade, staternas gränser överskridande (transnationella) brottsligheten; en konvention om denna brottslighet är under förberedelse..$^{51}$

För det tredje kan man observera att samtidigt som straffrätten och kriminalpolitiken internationaliseras, europeiseras de också. Även i andra världsdelar än Europa kan man konstatera en viss motsvarande, dock inte lika stark, regionaliseringsutveckling. I Europa medverkar i denna riktning de regionala organisationerna Europarådet och Europeiska unionen (EU). Dessa organisationer för sig och de inom dem skapade rättsregleringsmedlen bygger på demokratins, de mänskliga rättigheternas och rättsstatens värden. Betydelsen av dessa värden och principer har man accentuerat i samband med att de Mellaneuropeiska och Östeuropeiska forna socialiststaterna under 1990-talet anslutit sig till Europarådet. För EU och dess medlemsstater har de gemensamma ekonomiska intressena ökat trycket att harmonisera medlemsstaternas straffrätt och till och med utveckla en egen EU-straffrätt. ${ }^{52}$

I vilken mån avspeglar de beskrivna utvecklingsdragen och de vidtagna åtgärderna en sådan kriminalpolitik som är acceptabel ur en nordisk synvinkel? För att kunna svara på denna fråga behövs konkretiseringar - till först beträffande den internationella kriminalpolitiken.

Det finns olika uppfattningar om de internationella brottmålsdomstolarnas legitima uppgifter och deras verkningar. Deras verksamhet har en accentuerat symbolisk funktion, att antyda ogillande. Flera omständigheter medverkar till i vilken omfattning man medelst verksamheten på längre sikt förmår nå sådana (indirekta) positiva allmänpreventiva verkningar, såsom förstärkningen av de för det internationella samfundets existens fundamentalt viktiga humanitära värdena och rättviseprinciperna (civitas maxima -tanken). Är dessa brottmålsdomstolar kapabla att fungera ens drägligt effektivt samt är selektionen av de åtalade rimligt rättvis? Dessa omständigheter är viktiga med tanke på domstolsverksamhetens legitimitet. ${ }^{53}$

Det är alltför tidigt att i detta skede göra en värdering. Exempelvis till den internationella brottmålsdomstolen i Haag hade man fram till 31.3.1999 stämt in 59 personer, men av dessa hade endast 26 kunnat fängslas för att svara på åtalen. ${ }^{54}$ Mycket centralt för framgången är att staterna och andra instanser bistår med sin hjälp i internationella rättegångar och att staternas nationella straffrätts- 
system tar sig an sitt primära ansvar vid rättsskipningen beträffande även dessa brott.

För det andra om den europeiska kriminalpolitikens utmaningar: Vissa gemensamma rättsliga traditioner och rättsliga institutioner, som upprätthåller dem - särskilt Europarådet och EU -, har i Europa tillnärmat medlemsstaternas kriminalpolitik. Europarådets viktigaste regleringsmedel är givetvis konventionen om de mänskliga rättigheterna som härstammar från år 1950 och som förnyats år 1998. Mycket betydande är även de mer än 20 multilaterala avtalen inom den internationella straff- och processrättens område; de senaste gäller miljöstraffrätt och korruption ${ }^{55}$. Inom Europarådet begränsas medlemsstaternas förpliktelser i brottmålsärenden till ett samarbete mellan regeringarna. Inom EU hör polis- och rättssamarbetet i brottmålsärenden på motsvarande sätt till den s.k. tredje pelaren, dvs. till samarbetet mellan regeringarna, även efter det s.k. Amsterdamavtalet (1999).

Den kända franska straffrättslärda Mireille Delmas-Marty har ställt frågan om vi inom den europeiska kriminalpolitiken är på väg mot en tillnärmning, harmonisering (i och med krav på gemensamma styrande principer och regleringens samstämmighet) eller ett förenhetligande, en uniformering (då man förutsätter likadana regler och regleringens enhetlighet). Enligt henne rör vi oss i bägge riktningarna, och särskilt viktigt är att fästa uppmärksamhet vid de gemensamma principerna som utformats i och med den europeiska konventionen om de mänskliga rättigheterna och EG-rätten. ${ }^{56}$ Emedan stadgandet av bindande straffrättsliga författningar varken hör till Europeiska gemenskapens eller Europarådets officiella behörighet, är dessa institutioners inverkan på straffrätten indirekt, bestämd av gemensamma principer. ${ }^{57}$

Gemenskapsrättens medelbara verkan har inriktats närmast på straffrätten, och verkan av den europeiska konventionen om de mänskliga rättigheterna har inriktats primärt på straffprocessrätten. Den senaste rättsutvecklingen tyder på att EG-rättens nämnda harmoniserande inverkan på straffrätten är svår att förutse och den är ett resultat av en komplicerad process. ${ }^{58}$

I det i EU accepterade Amsterdamavtalets tredje pelare har man ställt som mål att utveckla EU till ett område baserat på frihet, säkerhet och rättvisa. Härvid är det även meningen att man utvidgar den rättsliga och demokratiska kontrollen av användningen av regleringsmedlen, man integrerar Schengen-regleringen som en del av EU och erkänner Europols centrala roll..$^{59}$

Beträffande den europeiska straffrättspolitikens tillnärmning och förenhetligande har nyligen två från varandra mycket avvikande förslag presenterats. För det första har den tyska professorn Ulrich Sieber på uppdrag av Europarådet utgivit en promemoria beträffande berättigandet av en europeisk modellstrafflag. ${ }^{60}$ På initiativ av Francesco de Angelis, dåvarande direktör för kommissionens generaldirektorat för tillsynen över finansförvaltningen (DG XX), har en akademisk sakkunniggrupp förberett ett förslag "Corpus Juris" (1997). Försla- 
get inbegriper straffrättsliga bestämmelser, medelst vilka man skulle trygga EU:s ekonomiska intressen inom det europeiska rättsområdet genom ett mera rättvist, enkelt och effektivt straffrättsligt system. Reglerna baserar sig på sju principer (inom straffrätten: legalitets-, skuld och proportionalitetsprincipen, samt inom straffprocessrätten: territorial- och subsidiaritetsprincipen samt den kontradiktoriska principen och den rättsliga kontrollens princip) ${ }^{61}$ Man har nyligen publicerat en granskad version av Corpus Juris -förslaget (2000). ${ }^{62}$

En europeisk modellstrafflag skulle representera en "mjuk" tillnärmning av staternas straffrättssystem. En dylik linje har inom de nordiska länderna förespråkats av bl.a. Vagn Greve, som är en sträng motståndare till det "hårda" förenhetligandet på straffrättens moraliskt laddade områden.$^{63}$ De nordiska straffrättsforskarna har även i allmänhet ställt sig kritiskt till Corpus Juris -förslaget. Man har varit rädd för att en allmäneuropeisk reglering i enlighet med förslaget skulle äventyra centrala värdemålsättningar som är kännetecknande för de nordiska ländernas rättskultur och kriminalpolitik. I detta tänkesätt poängteras bl.a. förebyggande av brottsligheten samt de för kriminal- och straffrättspolitiken ställda kraven på legitimitet, relativt låg repressionsnivå och humanitet. ${ }^{64}$

För dessa kritiska anmärkningar är frågan om straffrättssystemets legitimitet särskilt viktig. Den transnationella allmäneuropeiska kriminal- och straffrättspolitikens godtagbarhet är svår att uppnå bland medborgarna. Inom det nordiska rättsområdet är det lättare att uppnå förtroende för de andra ländernas rättssystem på grund av de gemensamma rättsliga och kulturella traditionerna. Ifall man önskar förstärka ett liknande förtroende för EU:s verksamhet och organ, borde man tydligen förkovra den allmänna vetskapen om allmäneuropeiska värden, förbättra öppenheten vid förfaranden för beslutsfattande, samt förstärka individernas ställning och rättigheter. ${ }^{65}$

En riktning mot ett förenhetligande eller i varje fall en tillnärmning av kriminalpolitiken kan skönjas såväl på ett globalt (FN) som ett europeiskt (Europarådet och EU) plan. Ur synvinkeln för kriminalpolitikens rationalitetskriterier har i allmännordiska och finska diskussioner vissa oroväckande drag i denna utveckling poängterats, om ock dessa länder alltmer aktivt borde sträva efter att inverka på innehållet $\mathrm{i}$ denna politik. Det borde kanske skapas ett handlingsprogram eller strategier för att förbättra den nordiska kriminalpolitikens inflytande på denna utveckling. Den nordiska rättstraditionen, det effektiva rättsliga samarbetet mellan de nordiska länderna och dessa länders humana kriminalpolitik kan erbjuda medel för att förstå och utveckla förutsättningar för ett motsvarande rättsligt område utan gränser inom EU. ${ }^{66}$

Ett positivt drag är fastställandet av den internationella straffrättens system då man bringat de allvarliga kränkningarna av den humanitära rätten till de etablerade internationella brottmålsdomstolarnas jurisdiktion. Även i dessa fall - och ännu tydligare i andra typer av brott - blir det straffrättsliga samarbetet mellan 
staterna och de interna straffrättsliga systemens funktionsduglighet avgörande för hur väl de åtalade får bära sitt ansvar. Samarbetet i brottmålsärenden mellan staterna befrämjas, ifall staternas kriminal- och straffrättspolitik står nära varandra. Viktigare än denna enhetlighet är dock hur legitimt man upplever ett främmande (straff)rättssystem - framför allt hur väl de demokratiska, människorättsliga och rättsstatliga värdena och principerna där förverkligas.

\section{Slutord}

Jag har behandlat den nordiska kriminalpolitikens utveckling utgående från en ganska idealiserad och optimistisk bild av kriminalpolitikens (kommunikativa) rationalitet. De faktorer som i ökande utsträckning hotar denna rationalitet har också berörts. Verkningar av kriminalpolitikens internationalisering och europeisering har särskilt analyserats. Min utgångspunkt att till forskningens och forskarnas uppgifter hänföra skapandet av förutsättningar för en rationell och human kriminalpolitik har återspeglat sig i min framställning.

Till slut återkommer jag till Inkeri Anttilas ovannämnda distinktion mellan konservativ och radikal kriminalpolitik. Den hastighet med vilken institutioner, värderingar, legala system och attityder förändrar sig har tilltagit ännu mer. Den kända forskaren i straffandets socialhistoria David Garland skriver: "A sure sign that we are indeed in a state of transition, occupying the unsettled terrain betwixt and between different policy regimes, is the uncertain character of today's penal politics. The battle lines of penal debate are blurred and constantly changing. No one today is quite sure what is radical and what is reactionary. ${ }^{67}$ Det är klart att forskningen i denna situation är full av utmaningar.

Noter:

' Publicerat i NTfK 1967 s. 237-251.

${ }^{2}$ Jfr. generellt två färska artiklar, den ena av dansken Lars Nordskov Nielsen, Bølger i den kriminalpolitiske udvikling. NTfK 1999 s. 261-279 och den andra av finländaren Tapio Lappi-Seppälä, Kriminalpolitik - straffrättspolitik. NTfK 2000 s. 113-135.

${ }^{3}$ Jfr. generellt Petter Asp, EG:s sanktionsrätt. Ett straffrättsligt perspektiv. Uppsala 1998. Se även Tuomas Pöysti, Det framtida europeiska rättsområdet och Norden. I verket Nordisk identitet. Nordisk rätt i europeisk gemenskap. Red. av Pia Letto-Vanamo. Helsingfors 1998, s. 139-156 (153).

${ }^{4}$ Se särsk. Inkeri Anttila - Patrik Törnudd, Kriminologi i kriminalpolitiskt perspektiv. En lärobok. Stockholm 1973 och Raimo Lahti, Kriminalvetenskaplig forskning och kriminalpolitik. NTfK 1986 s. 353-362.

${ }^{5}$ Jfr. Panu Minkkinen, Straffrätten, ultima ratio -principen och den kritiska rättsläran. I verket Skuldfrihet och ansvarslöshet. En hälsning till Alvar Nelson på 75 årsdagen. Utg. av Kerstin Berglund et al. Helsingfors 1994, s. 125-139.

6 T.ex. Britta Kyvsgaard skriver om "[m]otsättningarnas kriminalpolitik". I antologin "8 reflektioner om kriminalpolitik". BRÅ-Rapport 1999:9. Stockholm 1999, s. 36-54.

${ }^{7}$ Se NTfK 1967 s. 237, 250-251.

${ }^{8}$ Med anledning av det följande se vidare t.ex. Anttila, NTfK 1967 s. 237-243; Lahti, Idéutvecklingen beträffande kriminalitet och straffsystem. JFT 1979 s. 652-658; Johs. Andences, Nyklassisisme, proporsjonalitet og prevensjon. NTfK 1988 s. 41-48.

- Nordskov Nielsen ser den danska lagen från år 1905 som den första nämndvärda nya böljan i Danmarks kriminalpolitiska utveckling, NTfK 1999 s. 261, 265. 
${ }^{10}$ Se särsk. Christie, Tvangsarbeid og alkoholbruk. Oslo 1960; samma, Reaksjonenes virkninger. NTfK 1961 s. 129-144; Anttila, NTfK 1967 s. 239-243 (med hänvisningar).

"Se Lars D. Eriksson (red.), Varning för vård. Helsingfors 1967; Hans Nestius (red.), Behandling som straff. Stockholm 1969.

${ }^{12}$ I den nämnda ordningen Kommittébetänkande 1976:72 (Helsingfors 1977; en svensk översättning, förutom kap. I och VI, i två band 1978), BRÅ-Rapport 1977:7 (Stockholm 1977), Stortingsmelding nr. 104, 1977-78, Om Kriminalpolitikken (Oslo 1978) och Betænkning nr. 806/1977 (Kobenhavn 1977).

${ }^{13}$ Boken var redigerad av Sten Heckscher, Annika Snare, Hannu Takala och Jørn Vestergaard (Stockholm 1980). Boken innehöll bl.a. de bidrag som Nils Christie och Patrik Törnudd framförde på kriminalistmötet i Oslo (om de sistnämnda se även NTfK 1979 s. 5-26). Märk även konferenspublikationen Straffesystemer i Norden. Nordiska rådet, NU B 1977:25.

${ }^{14}$ Utförligt om allmänprevention se särsk. Johannes Andenaes, Punishment and Deterrence. Ann Arbor 1974; samma, Straff, almenprevensjon og kriminalpolitikk. Oslo 1990.

${ }^{15}$ Se Törnudd, i verket Straff och rättfärdighet s. 140-141; P.O. Träskman m.fl., Tio år med straffvärdet. NTfK 2000 s. 136-153. A Sveriges del se även jubileumsnummer "Påföljdsbestämning". SvJT 2/1999.

${ }^{16}$ Motiveringen utgick från proportionalitets- och rättssäkerhetsaspekter men anslöt sig inte till misstron till behandlingstanken. Så Nordskov Nielsen, NTfK 1999 s. 269, 274, 278.

${ }^{17}$ Se t.ex. artiklar i rapporten Organised Crime \& Crime Prevention - what works? Nordisk Samarbejdsråd for Kriminologi, København 1998, s. 213-260.

${ }^{18}$ Se artiklarna av Ingrid Sahlin och Nils Christie, i rapporten Organised Crime \& Crime Prevention - what works? s. 232-260 (Christies artikel är publicerad även i NTfK 1999 s. 5-15); Vagn Greve, Criminal Law in the 21st Century. I verket Peter Blume (ed.), Legal Issues at the Dawn of the New Millennium. Copenhagen 1999, s. 37-56 (47).

${ }^{19}$ Se närmare Anttila - Törnudd, Kriminologi i kriminalpolitiskt perspektiv s. 140-145.

${ }^{20}$ Se Törnudd, Kriminalpolitik och brottsprevention. JFT 1994 s. 403-415; samma, Facts, Values and Visions. National Research Institute of Legal Policy, Helsinki 1996, s. 163-180; Lappi-Seppälä, Kriminalpolitikens framgång? Bra och dåligt i finsk kriminalpolitik. JFT 1998 s. 237-257; samma, NTfK 2000 s. 113-135.

${ }^{21}$ Närmare om fångtalen från en komparativ synvinkel se två samlingar av seminarinlägg: NTfK 2/1996; Prison Population in Europe and in North America. Ministry of Justice, Helsinki 1997.

${ }^{22}$ Så Andenaes, Punishment and Deterrence s. 170:" [value questions] will have to be faced more squarely."

${ }^{23}$ Se närmare t.ex. Aulis Aarnio, The Rational as Reasonable. Dordrecht 1987, kap. IV.2.4 (the general conditions of rational discourse).

${ }^{24}$ Begrepp och brottsbeskrivning. Stockholm 1974, s. 229.

${ }^{25}$ Om den professionssociologiska ändringen - i synnerhet om ekonomisternas ökande roll - i kriminalpolitiken se Greve, Tendenser i det strafferetlige system. SvJT 1997 s. 597-618 (613-615).

${ }^{26}$ Se t.ex. diagrammet och tolkningen i Christie, Hvordan er Danmark mulig? NTfK 1999 s. 280291 (281).

${ }^{27}$ Den förstnämnda boken var redigerad av Gunilla Wiklung (Brottsförebyggande rådet, Stockholm 1990) och den sistnämnda boken med undertitel "Om vådan av den nyttiga straffrätten" av Dag Victor (Stockholm 1995).

28 "8 reflektioner om kriminalpolitik". BRÅ-Rapport 1999:9. Stockholm 1999.

${ }^{29}$ Vilken sorts straffrätt vill vi ha? - Om defensiv och offensiv straffrättspolitik. I antologin Varning för straff s. 19-37. Såsom Jareborg hänvisar, har Winfried Hassemers produktion påverkat hans grundkonception.

${ }^{30}$ Se därom Lahti, Vad bör straffas och hur strängt bör straffet vara? I Lov og frihet. Festskrift til Johs. Andenæs. Oslo 1982, s. 205-200; Pekka Koskinen, "Totalrevideringen av strafflagen slutförs”. NTfK 1998 s. 271-279. 
${ }^{31}$ Jfr. generellt Greve, SvJT 1997 s. 597-605, 611; samma, i verket Legal Issues at the Dawn of the New Millennium s. 40-47 (s. 46: "Our present system of criminal law and its development is thus characterized by conflicting types of view of society").

${ }^{32} \AA$ straffrättens del se särsk. Ari-Matti Nuutila, Rikosoikeudellinen huolimattomuus [Straffrättslig oaktsamhet]. Helsinki 1996, kap. II.2.

${ }^{33}$ Träskman har betecknat den europeiska människorättskonventionen (1950) som 1900-talets Stora Lag, men samtidigt noterat vissa inskränkningar i konventionen och dess tillämpningspraxis, t.ex. konventionens begränsade roll i förhållande till den materiella straffrätten. En gemensam europeisk strafflag begränsar nationell kriminalpolitik. I antologin 8 reflektioner om kriminalpolitik s. 118-139 (129-130).

${ }^{34}$ I det sistnämnda hänseendet se Kyvsgaard, Den samhälleliga polariseringen och oskadliggörande av lagöverträdare. I antologin Varning för straff s. 110-136.

${ }^{35}$ Se närmare t.ex. Rapport fra kontaktseminar om samfunnstjeneste. Nordisk Samarbejsråd for Kriminologi, Reykjavik 1992.

${ }^{36}$ Rikollisuustilanne [Brottslighetssituationen] 1998. Rättspolitiska forskningsinstitutet. Helsinki 1999, s. 195-198.

${ }^{37}$ Se närmare t.ex. Annika Snare, "Restorative justice" - om genomprettende retfærdighed. I Grønland - på vej mod et nyt straffesystem? Rapport fra NSfK's 41. forskerseminar. København 1999, s. 97-103; Christie, NTfK 1999 s. 287-291. Om tidigare ståndpunkter se t.ex. Ulla Bondeson, Nya icke-frihetsberövande sanktioner. I antologin Nordiska kriminologier om 90-talets kriminalpolitik s. 116-132; Juhani Iivari, The Process of Mediation in Finland. I verket H. Messmer and H.U. Otto (eds.), Restorative Justice on Trial. Kluwer Academic Publishers 1992, s. 137-147.

${ }^{38}$ Se närmare Kyvsgaard, Supervision of Offenders: Can an Old-fashioned Service System be of Any Service in the Case of Present-day Offenders? Journal of Scandinavian Studies in Criminology and Crime Prevention, vol. 1, 2000 s. 73-86; samma, i antologin 8 reflektioner om kriminalpolitiken s. 43-44; Nordskov Nielsen, NTfK 1999 s. 272-278; Lappi-Seppälä, NTfK 2000 s. 121124.

${ }^{39}$ Se särsk. Thomas Mathiesen, Straffpolitiken inför 1990-talet - en studie i moralisk panik. I antologin Nordiska kriminologer om 90-talets kriminalpolitik s. 13-28 (varifrån också terminologin härstammar); Dag Victor, Politik och straffsystem - ett drama under utveckling, I antologin Varning för straff s. 57-77.

${ }^{40} \mathrm{Se}$ - förutom ovan i not 39 nämnd litteratur - t.ex. Greve, SvJT 1997 s. 605-611; Flemming Balvig, Den kriminologiske forskning og kriminalpolitiken. I Rapport Vilkårene i den retspolitiske debat, ret og etik - kundskab og makt. Københavns Universitet 1999, s. 47-75; Kyvsgaard, i antologin 8 reflektioner om kriminalpolitiken s. 49-53.

41 Se särsk. Träskman, i verket Varning för straff s. 149-160 (varifrån även terminologin härstammar).

${ }^{42}$ Se Koskinen, NTfK 1998 s. 278; Lappi-Seppälä, NTfK 2000 s. 129-132. Båda ser dock hotbilder.

${ }^{43}$ I det sistnämnda hänseendet har Flemming Balvig (Folket, juristerna och straffrätten, i antologin 8 reflektioner om kriminalpolitiken s. 9-35) en vision om förpliktande närhet; Gerry Johnstone (Penal Policy Making: Elitist, populist or participatory? Punishment \& Society, vol. 2, 2000, s. 161-180) talar för participation.

${ }^{44}$ Se om detta t.ex. Törnudd, JFT 1994 s. 411-412; Lappi-Seppälä, NTfK 2000 s. 127-128.

${ }^{45}$ Andences, NTfK 1988 s. 48.

${ }^{46}$ Se närmare t.ex. artiklarna av Jukka Kekkonen, Jørgen Jepsen, Thorsteinn A. Jonsson och HansGunnar Axberger om "Hva styr kriminalpolitikken?", i Rapport från 31. nordiska forskarseminariet i Larkollen, Norge 1989 (Nordiska samarbetsrådet för kriminologi); Henrik Tham, Från behandling till straffvärde, i verket Varning för straff s. 78-109.

${ }^{47}$ Se närmare t.ex. Kekkonen, i Rapport från 31. nordiska forskarseminariet s. 108, 112; David Garland, The Limits of the Sovereign State. The British Journal of Criminology, vol. 36, 1996, s. 445471 (460-461); Greve, SvJT 1997 s. 615, 617-618.

${ }^{48}$ Se generellt Lahti, Towards an International and European Criminal Policy? I verket Liber Amicorum Bengt Broms. Helsinki 1999, s. 222-240 (med hänvisningar). 